\title{
Data on biology and ecology of Pseudaulacaspis pentagona (Targioni Tozzetti) (Hemiptera: Diaspididae) on fruit trees in the Peloponnese
}

\section{George J. Stathas ${ }^{1 *}$, A. Kostriva ${ }^{1}$, Panagiotis J. Skouras ${ }^{1}$, Dimitrios C. Kontodimas ${ }^{2}$, Ch.F. Karipidis ${ }^{3}$}

\author{
${ }^{1}$ University of Peloponnese, Antikalamos, Greece \\ ${ }^{2}$ Benaki Phytopathological Institute, Kifissia, Greece \\ ${ }^{3}$ University of Ioannina, Arta, Greece \\ *Corresponding author: gstathas@teikal.gr
}

\begin{abstract}
The study was conducted In Kalamata, Messinia, province of the Peloponnese, where infestations of Pseudauacaspis pentagona (Targioni Tozzetti) (Hemiptera: Diaspididae) were found on kiwi trees Actinidia deliciosa (Actinidiaceae), peach trees Prunus persica (Rosaceae) and mulberry trees Morus alba (Moraceae). Data on biology and ecology of the scale were recorded by samplings of infested branches of mulberry trees and by examining them in the laboratory, during the years 2016-2018. Pseudaulacaspis pentagona is an oviparous and amphigonic species. The fecundity of the scale fluctuated between 97 and 133 eggs per female. In the area of Kalamata it completed 3 generations per year and overwintered as mated pre-ovipositing female. The main natural enemies of P. pentagona recorded in the area of Kalamata are the coccinellid predators: Chilocorus bipustulatus (L.) and Rhyzobius lophanthae Blaisdell.
\end{abstract}

Keywords: fecundity, natural enemies, predators, Pseudaulacaspis pentagona

Article history:

Received: 27 February 2020. Accepted: 15 March 2020

For citation:

Stathas GJ, Kostriva A, Skouras PJ, Kontodimas DC, Karipidis CF. Data on biology and ecology of Pseudaulacaspis pentagona (Targioni Tozzetti) (Hemiptera: Diaspididae) on fruit trees in the Peloponnese. RUDN Journal of Agronomy and Animal Industries. 2020; 15(2):142—149. doi: 10.22363/2312-797X-2020-15-2-142-149

\section{Introduction}

The scale insect Pseudaulacaspis pentagona (Targioni Tozzetti) (Hemiptera: Diaspididae) is a polyphagous species, which originated from Asia (Japan or China) and it is widespread worldwide. It has been recorded in 110 countries on 221 host plant species, belonging to 85 plant families. In many regions of the world, such as in the

(C) Stathas G.J., Kostriva A., Skouras P.J., Kontodimas D.C., Karipidis Ch.F., 2020. 
United States of America: Florida, Carolina, Virginia, in Mediterranean coast and adjacent areas, in Asia: Taiwan, it is considered as one of the main insect pests of fruit trees and ornamental plants, causing serious economic damage [1]. It completes 2 to 4 generations per year in several countries, depending on the climatic conditions and the host plant species. Regarding the phenology of $P$. pentagona, the scale completes 2 generations per year in Switzerland [2], 4 generations in northern Florida [3], 3 in Virginia and 3 in Maryland [4], 4-5 in Bermuda [5], 3 in the Mediterranean part of France and Italy [1, 6], 3 in Romania [1], 3-4 in Turkey [1, 7]; 3 in Russia [8] and 3 in Japan [9].

Many natural enemies of $P$. pentagona have been recorded in several regions of the world, such as Hymenoptera of the families Aphelinidae, Encyrtidae, Eulophidae, Halictidae, Signiphoridae, Trichogrammatidae, Diptera of the family Cecidomyiidae, Neuroptera of the family Chrysopidae, Lepidoptera of the families Noctuidae and Arctiidae, Coleoptera of the family Coccinellidae, mites of the families Hemisarcoptidae and Tetranychidae and entomopathogenic fungus of the family Cordycipitaceae [1].

The presence of $P$. pentagona has been recorded in Greece by Balachowsky [10], Paloukis and Mentzelos [11], Paloukis [12, 13] and Argyriou et al. [14]. The phenology of the scale has been studied in Northern Greece, in Central Macedonia on peach trees, where 3 generations were recorded per year, according to the male flight monitoring, using sex pheromone traps [15]. The records of the scale in Northern Greece according to the above mentioned studies are presented in figure 1.

Due to the impact of $P$. pentagona as insect pest of fruit trees in many countries, and due to the lack of information on its ecology in Messinia province, Southern Greece (fig. 1), where serious damages were recorded by the scale on several fruit trees, such as on Actinidiadeliciosa, Prunuspersica and Morus alba, it was considered significant to study its phenology, biology and ecology in this area. The knowledge of the above characteristics of any harmful insect is very important to plan an effective Integrated Control Program.

\section{Materials and methods}

The study was made on the population of the scale insect Pseudaulacaspis pentagona (Targioni Tozzetti) (Hemiptera: Diaspididae) infesting Morus alba (Moraceae) in Kalamata, Messinia, province of the Peloponnese, during January 2016 — December 2018.

For the study of the phenology, samples of infested shoots were collected from trees every two weeks and were transferred in plastic bags to the laboratory. The samples were consisted of $10 \ldots 15$ infested shoots having a length of about $10 \mathrm{~cm}$. The samples were examined under the stereoscope and the number of each developmental stage of the scale and the numbers of parasitized and predated scales were recorded.

The total number of each developmental stage and the numbers of parasitized and predated scales were expressed as the percentage, $\%$, of the total number of the scale found per each sampling. As for parasitized, scales containing larvae and nymphs of parasitoids and scales with exit holes of parasitoids were counted. As for predated, scales having damaged scale cover were counted.

The fecundity was studied by counting the total number of eggs found under the scale cover of 25 ovipositing female adults on 20/9/2017. 


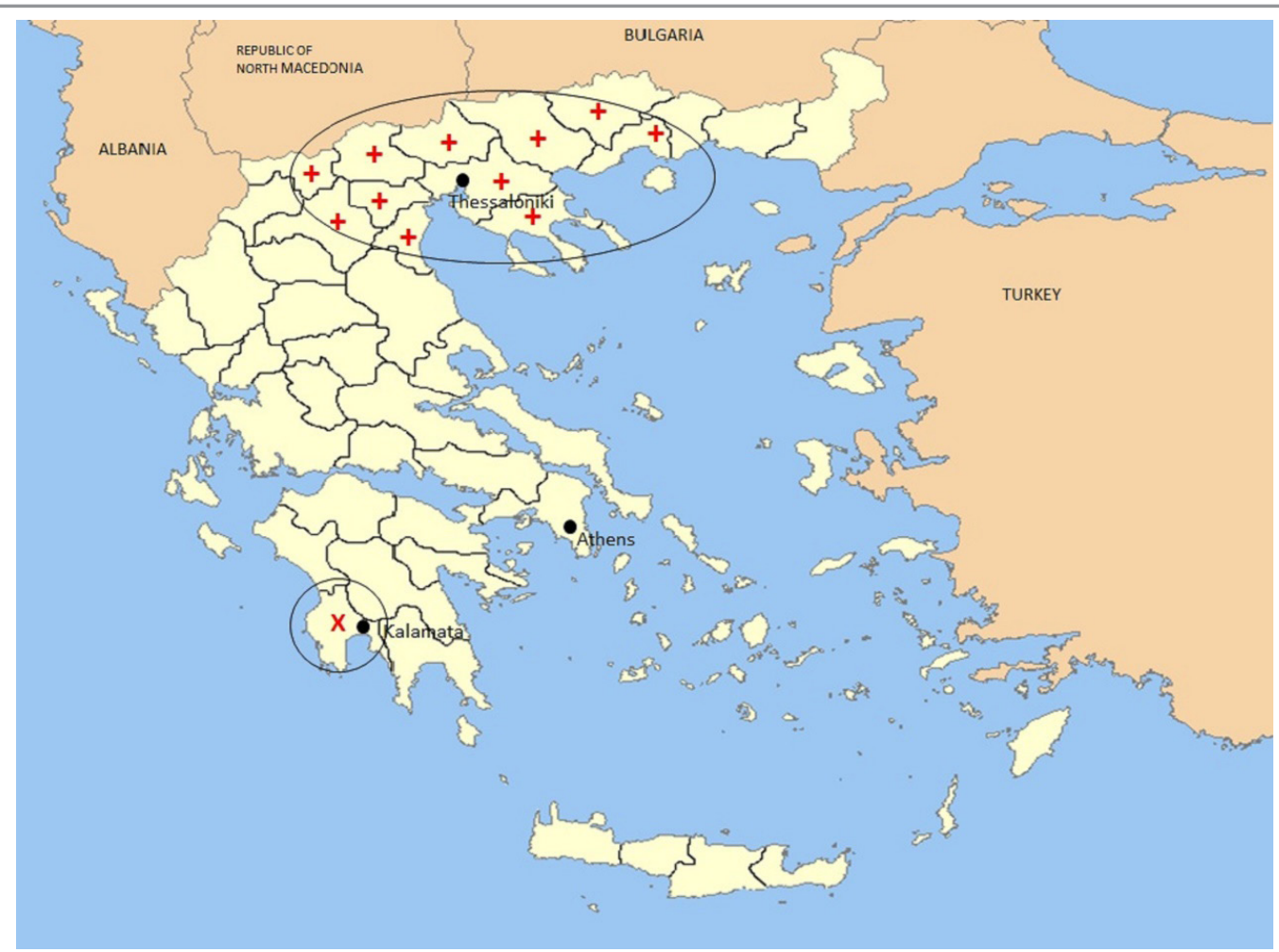

Fig. 1. Records of Pseudaulacaspis pentagona: +- in the provinces of Northern Greece; $X$ - in Messinia province (Southern Greece), during the present study

\section{Results}

Pseudaulacaspis pentagona was found in the area of Kalamata infesting kiwi trees Actinidia deliciosa (Actinidiaceae), peach trees Prunuspersica (Rosaceae) and mulberry trees Morus alba (Moraceae). It is an oviparous biparental species.

The phenology of $P$. pentagona on $M$. alba in Kalamata during the two year study is presented in fig. 2. As it seems in this figure, the scale completed 3 generations per year, in both years of the study. The peaks of the numbers of the crawlers appeared by the end of April, the beginning of July and the middle of September, in both years (fig. 2a). Later, appeared the settled $1^{\text {st }}$ instar nymphs and the $2^{\text {nd }}$ instar nymphs (fig. 2b). Fig. 2c shows the fluctuation both of the male nymphs of the scale developed under their scale cover and the pre-ovipositing female adults. In fig. $2 \mathrm{~d}$, are seemed the three peaks of the ovipositing female adults.

The number of eggs laid per female fluctuated between 97 and 133 eggs and the average fecundity was estimated to $118.5 \pm 25.7$ eggs per female.

In fig. 3 the percentage of parasitized and predated scales are presented. The parasitism rate reached to $21 \%$ in July of 2016 and to $18 \%$ in August of 2017. It was not possible to identify the ectoparasite species found on the samples. The percentage of predated scales reached to $35 \%$ on 2/8/2016 and to $28 \%$ on 4/7/2017. Individuals of larvae and adults of the coccinellid predators Chilocorus bipustulatus (L.) and Rhyzobius lophanthae Blaisdell were observed on the examined infested samples during June and September in both years of the study. 

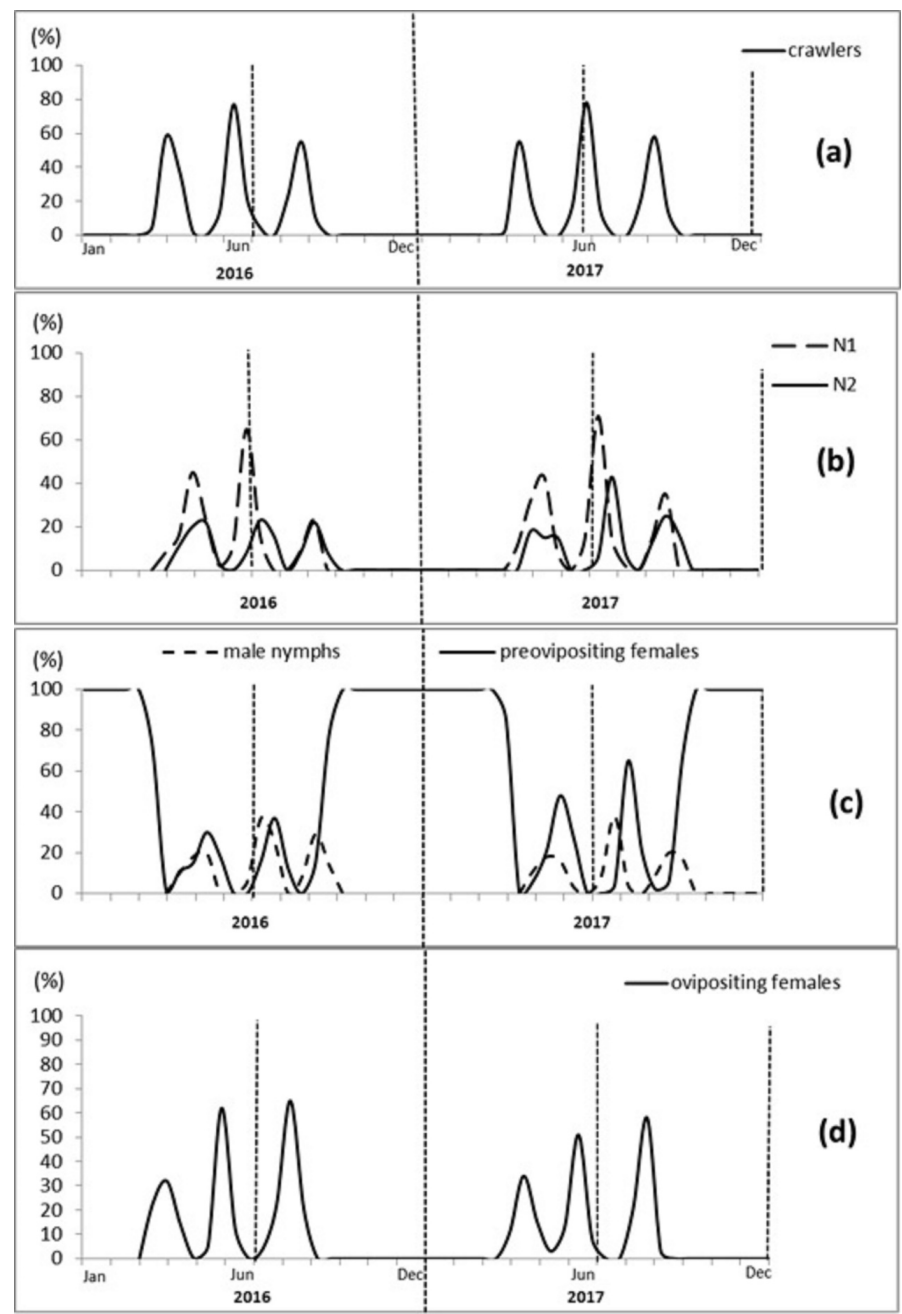

Fig. 2. Percentage of developmental stages of Pseudaulacaspis pentagona on Morus alba in Kalamata during 2016-2017

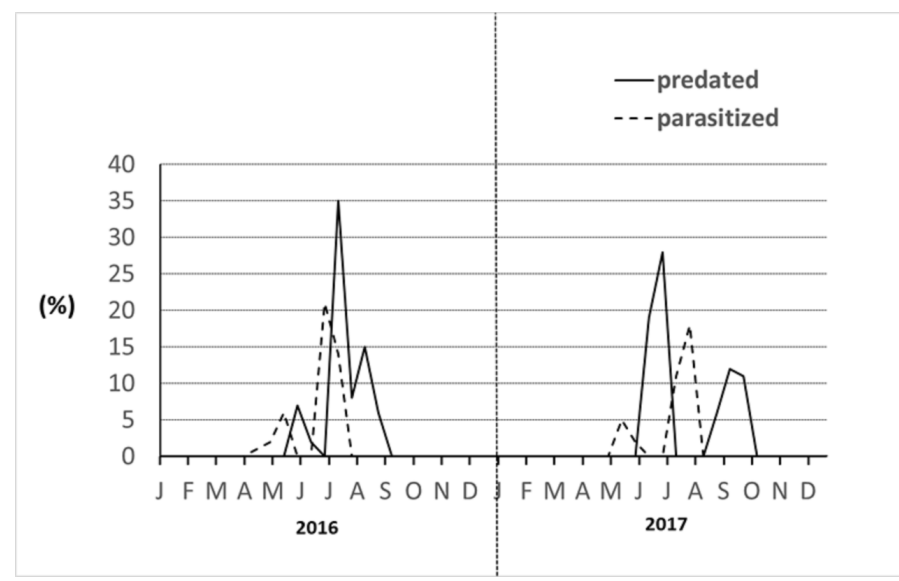

Fig. 3. Parasitized and predated Pseudaulacaspis pentagona, \%, on Morus alba in Kalamata during 2016-2017 


\section{Discussion}

Pseudaulacaspis pentagona on Morus alba completed 3 generations per year in Kalamata during 2016 and 2017. Similar results are referred to other studies of the scale in several countries. In Northern Greece on peach trees [15], in Virginia and in Maryland [4], in the Mediterranean part of France, in Italy and in Romania [1, 6], in Russia [8] and in Japan [9], P. pentagona is referred that it completed 3 generations per year. Nevertheless, 2 generations per year referred to in Switzerland [2] and 3-4 generations in Turkey. The above differences in the number of generations per year completed by $P$. pentagona could be attributed to differences in climatic conditions in the areas where the scale was studied. Beardsley \& Gonzalez [16] refer that in particular species, the rate of development and the number of generations per year may vary substantially in different regions. Climatic conditions, particularly temperature, humidity, and rainfall, appear to be the principal controlling factors.

As it seems in fig. 2c, the peaks of male nymphs appeared some days earlier than the appearance of preovipositing female adults to all generations of the scale. In the present study the flights of males were not recorded. But the earlier appearance of male nymphs in comparison to the female adults could indicate that male flights (after their development under the scale covers) occurred at the same time as the female adults' appearance. The presence of males in mid-September to mid-October, followed by the presence of adult females in both years of the study, indicates that the scale overwintered as mated female adult. The same way of over wintering (as mated female) is also reported to other countries as well, such as in Japan: Murakami [9] referred that males of the last generation appeared in early November to mate with the females which overwintered.

As far as it concerns the fecundity of $P$. pentagona, Danzing $[17,18]$ refers that each female lays about 140 eggs and Varga $[18,19]$ noted that $80 \ldots 100$ eggs were laid per female. The average number of eggs laid per female on M. alba in Kalamata found $118.5 \pm 25.7$. The number of eggs recorded in the present study, could be considered only indicative of the fecundity. It represents only the number of eggs found under the scales lifting the scale covers at the specific moment of the examination of the samples and not the total number of eggs that the females could give during their whole longevity. To measure the total fecundity of a scale, the females should be examined isolated during their whole longevity, using the micro-cage technique, under controlled conditions in the laboratory [20].

The parasitism of $P$. pentagona recorded to the present study was attributed to an unidentified ectoparasite. Argyriou, et al. [14] recorded the endoparasite Prospaltella berlesei Howard (Hymenoptera: Aphelinidae) as natural enemy of P. pentagona in Northern Greece. In the bibliography, many endoparasite and ectoparasites of the family Aphelinidae are referred in several countries as the natural enemies of the scale [1]. The predators of the scale found in Kalamata in this study, were the coccinelids $C$. bipustilatus and $R$. lophanthae. These species are referred as natural enemies of P. pentagona in other countries as well [1]. In Northern Greece, the predatory species Chilocoru ssp. and Rhyzobius (Lindorus) lophanthae are referred as predators of P. pentagona [14].

The knowledge of biology, phenology and natural enemies of the scales is necessary to plan an effective program of their Integrated Control. The above characteristics 
compose the ecology of the scale in a region and they could vary according to the climatic conditions and the host plant species. The present study held in Southern Greece on $M$. alba, gives some additional information about $P$. pentagona that could be useful to control of the scale in the region of Messinia, Peloponnese.

\section{Conclusions}

Pseudaulacaspis pentagona infesting Morus alba (Moraceae) in Southern Greece (Kalamata) was found to be an oviparous biparental species, completing 3 generations per year. The peaks in crawler numbers of the three generations were recorded at the end of April, beginning of July and middle of September. The differences in voltinism of the scale recorded in other countries (2-4 generations per year) could be attributed to the differences of the climatic conditions of the countries where the scale was studied.

The mean number of eggs of the scale found under the females in September of 2017 was $118.5 \pm 25.7$. This number could be considered as an indicative number of the total fecundity of the scale.

The parasitism rate of $P$. pentagona in Kalamata occurred due to the action of an unidentified ectoparasite species reaching to $21 \%$. No endoparasite was found on $P$. pentagona in Kalamata, as it was found in Northern Greece. In Kalamata, the main natural enemies of the scale were the coccinellid predators $C$. bipustulatus and $R$. lophantae, reaching a percentage of predated scales up to $35 \%$.

The data presented in this study, concerning phenology and ecology of $P$. pentagona, could attribute to the application of an effective Integrated Control program of the scale in Southern Greece.

\section{Refrences}

1. Morales MG, Denno BD, Miller DR, Miller GL, Ben-Dov Y, Hardy NB. ScaleNet: A literature-based model of scale insect biology and systematics. Database. 2016; Volume 2016: bav118. doi: 10.1093/database/bav118

2. Mani E, Kozár F, Schwaller F, Hippe C. The occurrence and biology of the mulberry scale, Pseudaulacaspis pentagona (Targioni-Tozzetti) (Homoptera: Diaspididae), in Switzerland. Mitteilungen der Schweizerischen Entomologischen Gesellschaft. 1997; 70(3-4):399-408. (In German)

3. Van Duyn J, Murphey M. Life history and control of white peach scale, Pseudaulacaspis pentagona (Homoptera: Coccoidea). The Florida Entomologist. 1971. 54(1):91—95. doi: 10.2307/3493794

4. Bobb ML, Weidhaas JA, Ponton LF. White peach scale: Life history and control studies. Journal of Economic Entomology. 1973: 66(6):1290-1292. doi: 10.1093/jee/66.6.1290

5. Bennett FD, Brown SW. Life history and sex determination in the diaspine scale Pseudaulacaspis pentagona (Targ.) (Coccoidea). Canadian Entomologist. 1958; 90(6):317-324. doi: 10.4039/Ent90317-6

6. Battaglia D, Di Leo A, Malinconico P, Rotundo G. Osservazioni sulla cocciniglia bianca del pesco e del gelso in Basilicata. Informatore Agrario. 1994; 50(3):77-80.

7. Bodenheimer FS. The Coccoidea of Turkey III. Revue de la Faculté des Sciences de l'Université d'Istanbul. 1953; 18:91-164.

8. Kunincka GM. Pseudaulacaspis pentagona Targ. Pseudaonidia paeoniae Ckll. Handbook of Quarantine and Other Dangerous Pests, Diseases and Weedy Plants. Boletin del Museo de Entomologia de la Universidad del Valle Kolos Moscow. 1970.

9. Murakami Y. A review of biology and ecology of Diaspine scales in Japan (Homoptera, Coccoidea). Mushi. 1970; 43:65-114.

10. Balachowsky AS. Les cochenilles Paléarctiques de la tribu des Diaspidini. Memmoires Scientifiques de l’Institut Pasteur. Paris; Institut Pasteur publ., 1954. (In French)

11. Paloukis SS, Mentzelos I. Contribution a l'étude de la bio-écologie et de la lutte de Pseudaulacaspis (Diaspis) pentagona Targ. (Homoptera: Diaspididae) ennemi du pêcher en Macedoine Centrale (Grèece). Station 
de Rècherche pour la Protection des Plantes, Thessalonique, Grèece, Bull. I. 1971.

12. Paloukis SS. The main scale insects of the fruit trees in Northern Greece. (In Greek). Plant Protection Institute of Thessaloniki. Thessaloniki, 1976; 148p.

13. Paloukis S. Studies on the bioecology and chemical control of scale insect pests of pome and stone fruit trees in Northern Greece. In: Proc. X Intern Symp. on Entomofaunistics. Central Europe, Budapest. 1983. p. 353-357.

14. Argyriou LC, Stavraki HG, Mourikis PA. A list of recorded entomophagous insects of Greece. Athens: Benaki Phytopathological Institute; 1976.

15. Kyparissoudas DS. Flight of White Peach Scale, Pseudaulacaspis pentagona, Males and Time of Crawler Appearance in Northern Greece. Entomologia Hellenica. 1992; 10:21—24.

16. Beardsley Jr JW, Gonzalez RH. The Biology and Ecology of Armored Scales. Annu. Rev. Entomol. 1975; 20(1):47-73.

17. Danzing EM. Cocoidea-Scale Insects. In: Nasekomye i kleshchi-vrediteli sel'skokhozyaistvennykh kul'tur [Insects and tick pests of agricultural crops] Leningrad: Nauka Publ.; 1972. p.189—221. (In Russ). Данциг E.M. Подотряд Соссоіdеа-Червецы или кокциды // Насекомые и клещи-вредители сельскохозяйственных культур. Ленинград: Наука, 1972. Т. 1. С. 189-221.

18. Kosztarab M, Kozár F. Scale Insects of Central Europe. Budapest, Hungary: Akademiai Kiado; 1988.

19. Varga I. Present distribution of mulberry scale (Pseudaulacaspis pentagona Targ.) in Hungary. Novenyvedelem 1971; 7(9):424—426. (In Hungarian)

20. Souissi R, Panis A. Estimation de la fécondité de deux cochenilles des arbres fruitiers Aspidiotus nerii Bouchéet Pseudaulacaspis pentagona (Targioni-Tozzetti) par la technique d’isolement sous micro-cages (Hemiptera: Diaspididae). Annales de la Société Entomologique de France. 1999; 35:87-92.

\footnotetext{
About authors:

Stathas George J. - Professor Laboratory of Agricultural Entomology and Zoology, Department of Agriculture, School of Agriculture and Food, University of Peloponnese, Antikalamos, Kalamata, 24100, Greece, e-mail: gstathas@teikal.gr

Kostriva A. - Laboratory of Agricultural Entomology and Zoology, Department of Agriculture, School of Agriculture and Food, University of Peloponnese, Antikalamos, Kalamata, 24100, Greece

Skouras Panagiotis J. - Phd, Laboratory of Agricultural Entomology and Zoology, Department of Agriculture, School of Agriculture and Food, University of Peloponnese, Antikalamos, Kalamata, 24100, Greece

Kontodimas Dimitrios C. - Phd, Head of Laboratory of Agricultural Entomology, Department of Entomology and Agricultural Zoology, Benaki Phytopathological Institute, 8 Stefanou Delta, Kifissia, 14561, Greece; e-mail: d.kontodimas@bpi.gr

Karipidis Ch.F. — Laboratory of Productive Agriculture and Plant Health, School of Agriculture, University of Ioannina, Arta, 47100, Greece
}

\title{
Особенности биологии и экологии Pseudaulacaspis pentagona (Targioni Tozzetti) (Hemiptera: Diaspididae), поражающей плодовые деревья на Пелопоннесе
}

\author{
Дж.Дж. Статас ${ }^{1 *}$, А. Кострива ${ }^{1}$, П.Дж. Скоурас ${ }^{1}$, Д.С. Контодимас², \\ Ч.Ф. Карипидис ${ }^{3}$
}

${ }^{1}$ Университет Пелопоннеса, Антикаламос, Греция

${ }^{2}$ Бенакиский институт фитопатологии, г. Кифисия, Греция

${ }^{3}$ Университет Янины, г. Арта, Греция

*gstathas@teikal.gr

Аннотация. Исследования были проведены в Каламате (Мессения, провинция Пелопоннес), где были обнаружены поражения тутовой щитовкой Pseudauacaspis pentagona (Targioni Tozzetti) (отряда Hemiptera, семейства Diaspididae) деревьев киви Actinidia deliciosa (Actinidiaceae), персика Prunus persica 
(Rosaceae) и шелковицы Morus alba (Moraceae). Данные по биологии и экологии щитовки были собраны путем отбора проб зараженных ветвей тутовых деревьев и исследования их в лаборатории в 2016-2018 гг. Размножается Pseudaulacaspis pentagona половым путем, после чего каждая самка откладывает от 97 до 133 яиц. В области Каламата за год развивается 3 поколения Pseudauacaspis pentagona, зимуют оплодотворенные самки. В данном районе основными естественными врагами P. pentagona являются хищные кокцинеллиды: Chilocorus bipustulatus (L.) и Rhyzobius lophanthae Blaisdell.

Ключевые слова: плодовитость, естественные враги, хищники, Pseudaulacaspis pentagona, тутовая щитовка

\section{История статьи:}

Поступила в редакцию: 27 февраля 2020 г. Принята к публикации: 15 марта 2020 г.

\section{Для цитирования:}

Stathas G.J., Kostriva A., Skouras P.J., Kontodimas D.C., Karipidis C.F. Data on biology and ecology of Pseudaulacaspis pentagona (Targioni Tozzetti) (Hemiptera: Diaspididae) on fruit trees in the Peloponnese // Вестник Российского университета дружбы народов. Серия: Агрономия и животноводство. 2020. Т. 15. № 2. C. 142 -149. doi: 10.22363/2312-797X-2020-15-2-142-149

\section{Об авторах:}

Статас Джорж Дж. - профессор, лаборатория сельскохозяйственной энтомологии и зоологии, Департамент сельского хозяйства, Школа сельского хозяйства и продовольствия, Университет Пелопоннеса, 24100, Греция, Каламата, Антикаламос; e-mail: gstathas@teikal.gr

Кострива А. - лаборатория сельскохозяйственной энтомологии и зоологии, Департамент сельского хозяйства, Школа сельского хозяйства и продовольствия, Университет Пелопоннеса, Греция, 24100, Каламата, Антикаламос

Скурас Панайотис Дж. - Phd, лаборатория сельскохозяйственной энтомологии и зоологии, департамент сельского хозяйства, Школа сельского хозяйства и продовольствия, Университет Пелопоннеса, Греция, 24100, Каламата, Антикаламос

Контодимас Димитрос C. - Phd, заведующий лабораторией сельскохозяйственной энтомологии, департамента энтомологии и сельскохозяйственной зоологии, Бенакиский институт фитопатологии, Греция, 14561, г. Кифисия, ул. Стефану Дельта, д. 8; e-mail: d.kontodimas@bpi.gr Карипидис Ч.Ф. - лаборатория продуктивного сельского хозяйства и здоровья растений, Школа сельского хозяйства, Университет Янины, Греция, 47100, г. Арта 